\title{
THE OCTOBER MEETING IN PROVIDENCE
}

The six hundred ninety-seventh meeting of the American Mathematical Society was held at Brown University, Providence, Rhode Island on Saturday, October 28, 1972. There were 77 registrants including 74 members of the Society.

By invitation of the Committee to Select Hour Speakers for Eastern Sectional Meetings, there were two hour addresses. Professor Ulf Grenander of Brown University spoke on Statistical geometry; he was introduced by Professor Walter F. Freiberger, the session being chaired by Professor Emilio O. Roxin. Professor Daniel B. Ray of the Massachusetts Institute of Technology spoke on Analytic torsion; he was introduced by Professor Katsumi Nomizu.

There were four sessions for ten-minute contributed papers, chaired by Professors Max K. Agoston, Gerasimos E. Ladas, Donald E. McClure, and Philip M. Whitman.

The headquarter offices of the Society were open for tours by attendees of the meeting.

Middletown, Connecticut

WALTER GotTSCHALK Associate Secretary 